Article

\title{
The Social Cost of Urban Sprinkling
}

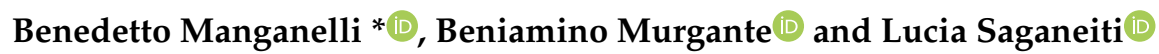

School of Engineering, University of Basilicata, 85100 Potenza, Italy; beniamino.murgante@unibas.it (B.M.); lucia.saganeiti@unibas.it (L.S.)

* Correspondence: benedetto.manganelli@unibas.it

Received: 29 January 2020; Accepted: 10 March 2020; Published: 13 March 2020

check for updates

\begin{abstract}
Low-density dispersed urban development, known as "sprawl" or "sprinkling", is an alternative configuration that best expresses the structure of the Italian urban system and is taking on increasingly significant dimensions. This phenomenon has increased in recent decades due to a weakening of the urban agglomeration force that had characterized the first half of the last century. Partial abandonment of agricultural activities and socio-economic changes led to the progressive urbanization of rural areas and the birth of widespread cities. This work discusses the externalities generated by sprawl, focusing on the tangible costs that this urban development model unloads on the people. In particular, the territory of the Basilicata Region is analyzed. Based on the data of some municipalities in the region, a relationship between the marginal costs relating to the greater linear infrastructure that sprinkling requires and an index already described in the literature to provide a quantitative measure of this phenomenon was built and verified with a regression model.
\end{abstract}

Keywords: sprinkling; sprawl; social cost; externalities; regression model

\section{Introduction}

Scientific research has been carried out on the environmental costs generated by urban transformation processes, focusing attention on soil sealing and soil consumption and the effects they produce [1]. The growth in the number of buildings, extraction activities, landfills, construction sites, yards, and other paved areas is representative of the processes of degradation and soil consumption which affect the whole European Union, although they do not equally affect the European member countries. The European Union has responded to this emergency with directives that underline the growing importance of the issue over the past 20 years (COM2002/179, COM 2006/231).

On the one hand, uncontrolled urban development, also known as sprawl, has generated ephemeral advantages for residents in new settlements, giving satisfaction to the desire to live in affordable single houses with a garden and more privacy [2]. On the other hand, it has led, as mentioned, to serious environmental, economic, and social consequences. The effects on the environment are consequent to the conversion of agricultural land into built or simply waterproofed areas that are no longer available for food production, and this has altered the landscape and led to drastic degradation of water quality [3] and air quality [4-6], loss of most of the ecological functions of soil [7], reduction of the resilience of ecosystems [8,9], and higher energy consumption [10,11]. Social effects are linked to the lengthening of commuting times, motor vehicle dependence, traffic congestion, and spatial separation of social classes [8,12-18].

Finally, there is an economic impact on people due to the greater expenditure on necessary infrastructure and public services. The impact of urban sprawl on local public costs does not have many examples in the literature. The first of these is by Ladd [19] who estimated a U-relation between the population and current public expenditure. The population exerts two contrasting forces: on the one hand, with the increase in population density, the per capita costs decrease due to economies of 
scale in the production of public services; on the other hand, the increase in the population entails an increase in public expenditure due to a greater demand for public services and congestion in the use of infrastructure. Carruthers and Ulfarsson [20] have shown that the per capita costs of many public services decrease with increasing population density and urbanization. In Spain, Hortas-Rico and Sole'-Olle' [21] finally highlighted a non-linear and growing relationship between widespread development and the costs of the main local public services.

In Italy, uncontrolled urban development has a specific form: sprinkling [22]. Sprinkling differs from the widespread development model (sprawl) because it has an extremely dispersed configuration in uneven and dimensionally variable aggregates, from single buildings to small conurbations, and with different uses, from residential to industrial or commercial, inserted in rural matrices without road networks and infrastructures designed based on organic patterns, but which had to support widespread and disordered building. Furthermore, the urban sprinkling phenomenon is characterized by very low population and building density values compared to those of the urban sprawl phenomenon. This research, starting from a quantitative measure of the sprinkling phenomenon, focused precisely on one of the least investigated aspects in the literature, namely on the economic impact that uncontrolled or poorly managed urban transformation generates on the population. In particular, the object of the study was the greater expenditure resulting from the infrastructure (roads, sewers, aqueducts, electricity network, etc.) necessary to connect these dispersed urban aggregates with the city center. It can be identified as one of the direct and monetizable social costs due to sprinkling. It therefore certainly represents an underestimate of the whole social cost whose potential rates have been previously described. The case study analyzed was that of the Basilicata region which, as demonstrated in other research [23,24], is a territory with a low population and settlement density. The territory is also affected by the phenomenon of urban sprinkling, especially in rural areas. Starting from the sprinkling index, the costs of transformation dynamics were analyzed.

In particular, this study tried to investigate whether greater urban fragmentation resulted in greater infrastructure expenses. The second section compares the two dynamics of transformation: urban sprawl and urban sprinkling. The following sections, starting from the description of the case study, construct the interpretative model and analyze the results obtained. In the conclusions, the results are discussed and commented on.

\section{Sprinkling vs. Sprawl}

In the early years of the twentieth century, the lack of transport systems and the weakness of the infrastructure itself led to the development of small settlements near to the established centers of cities in order to ensure easy access to public services. Since the second half of the century, however, the trend has completely inverted. The great increase in private mobility and the progressive reduction of restrictions on urban standards led to the crisis of the urban system, the loss of urban settlement cohesion, and the expansion of buildings in the rural area, mainly based on private investment. From the beginning of the 21st century, the dynamics of urban expansion have no longer been linked to the real need for new areas of expansion deriving from demographic growth. The new urban transformation is strongly correlated to low demand for new housing in a spatial planning system that is often ineffective in driving efficient urban development or in limiting and controlling speculative real estate initiatives.

Considering the main dynamics of urban transformation, urban sprawl is most diffused in the proximity of cities with high territorial density; on the other hand, in the proximity of cities with low settlement density, the dynamics of urban transformation are like the phenomenon of urban sprinkling. Both phenomena affect rural areas near urban centers with the construction of new residential settlements far from existing public services and marked by low levels of accessibility. They are characterized by low (urban sprawl) and very low (urban sprinkling) population density and building density indices. 
Among the various studies concerning the urban sprawl phenomenon [17,25-29], a generally shared definition of the term "urban sprawl" is "the spread of urban developments (such as houses and shopping centers) on undeveloped land near a city" (Merriam Webster [30]). The urban sprawl phenomenon indicates an urbanization model characterized by an unplanned and disorganized structure, a low population density (between 20 and 150 inhabitants per hectare), and a discontinuous building settlement (with density between 6 and 12 buildings per hectare) that originally spread along transport infrastructures and disorderly occupied large portions of land [31].

The dynamics of transformation that occurred (principally) in some regions of central and southern Italy after the Second World War led to phenomena of settlement dispersion different from those of urban sprawl, so much so that the need was felt to coin the new concept of urban sprinkling [23]. Sprinkling is defined as a small amount that falls into drops or scattered particles, and it is the best way to represent the configuration of the urbanized Italian territory.

This phenomenon has mainly affected the regions of central and southern Italy both in the hinterland and coastal areas. The phenomenon is typical of regions with very low settlement (between 0.1 and 0.8 buildings per hectare) and population density (between 0.2 and 2 inhabitants per hectare) whose territory is fragmented by settlements scattered in an uncontrolled way in the rural landscape [31]. Recently, urban sprinkling has also been studied and analyzed in different contexts from Italy, such as in research on African cities [32] and continental Portugal [33]. In some cases, this phenomenon originated from weak urban planning, in others, it was the consequence of abusive initiatives, encouraged by amnesties for the violation of building regulations. Moreover the phenomenon of urban sprinkling has also been investigated considering new components of the settlement system different from the traditional ones, i.e., renewable energy installations [34].

Knowledge of the different forms of urbanization is the basis for being able to effectively deal with the question of the sustainability of an urban development model.

As there is only a non-objective definition of sprawl [2,28], a series of indicators have been proposed to quantify it, ranging from single to multidimensional metrics [26,27,35-39], and sometimes the results are contradictory in measuring the expansion of certain cities [40].

As concerns urban sprinkling, an indicator that has already emerged as effective in expressing the transformation dynamics and territorial fragmentation is the Sprinkling index (SPX) [22].

\section{Materials and Methods}

In this research, measurement of the economic impact of sprinkling on the population was done through the preliminary estimate of additional costs due to the urbanization necessary for new settlements.

The estimate of the tangible costs that local administrations must bear due to this urbanization model was then related to the SPX index or, better, to the extent of its variation. For this, a regression model was used. The investigation was conducted on some municipalities in the Basilicata region. The time interval taken as reference was from 1950 to 2013.

To analyze the dynamics of sprinkling, together with the ISTAT data relating to the distribution of the population as of 2013, the following territorial data were acquired from the Regional Technical Map and from the Geo-Topographical Database of the geoportal of the Basilicata Region:

- the distribution of the buildings in 1950, deduced from the 1:25000 topographic map of the Military Geographical Institute;

- the distribution of the buildings in 2013;

- the settlement of the population in the various census sections; and

- the network of roads, classified by category, for each of the selected municipalities.

The above-mentioned data, downloaded in vector format, were subsequently processed and compared using the support of the open-source software QGIS. 


\subsection{Study Area}

The data provided by the National Institute of STATtistics (ISTAT) [41] between 1950 and 2013 relating to the entire region revealed a trend of an ever-decreasing population, mainly determined by migratory flows directed to other regions and by low birth rates. This decrease contrasted with the intense construction of new residential properties, which has recorded a constant percentage increase in the reference time interval (Figure 1).

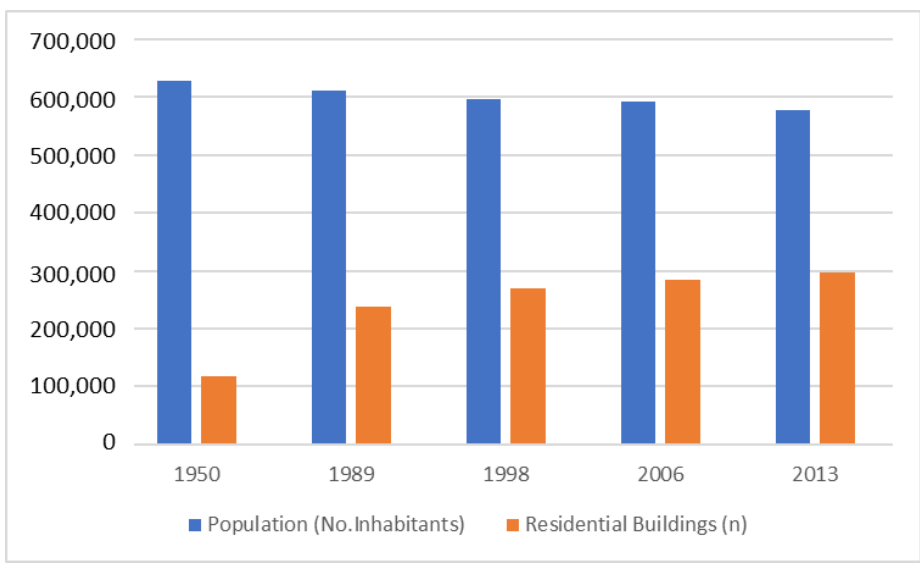

Figure 1. Population trend-residential buildings (1950-2013).

Figure 2 shows the map of Basilicata's municipalities classified by the degree of fragmentation and resident population in 2013 based on the results of previous research [24]. The municipalities analyzed in this work were also identified: Potenza, Matera, Melfi, Pisticci, and Lagonegro. An attempt was made to consider one municipality for each class of fragmentation without considering the low class of fragmentation in which very small municipalities are included.

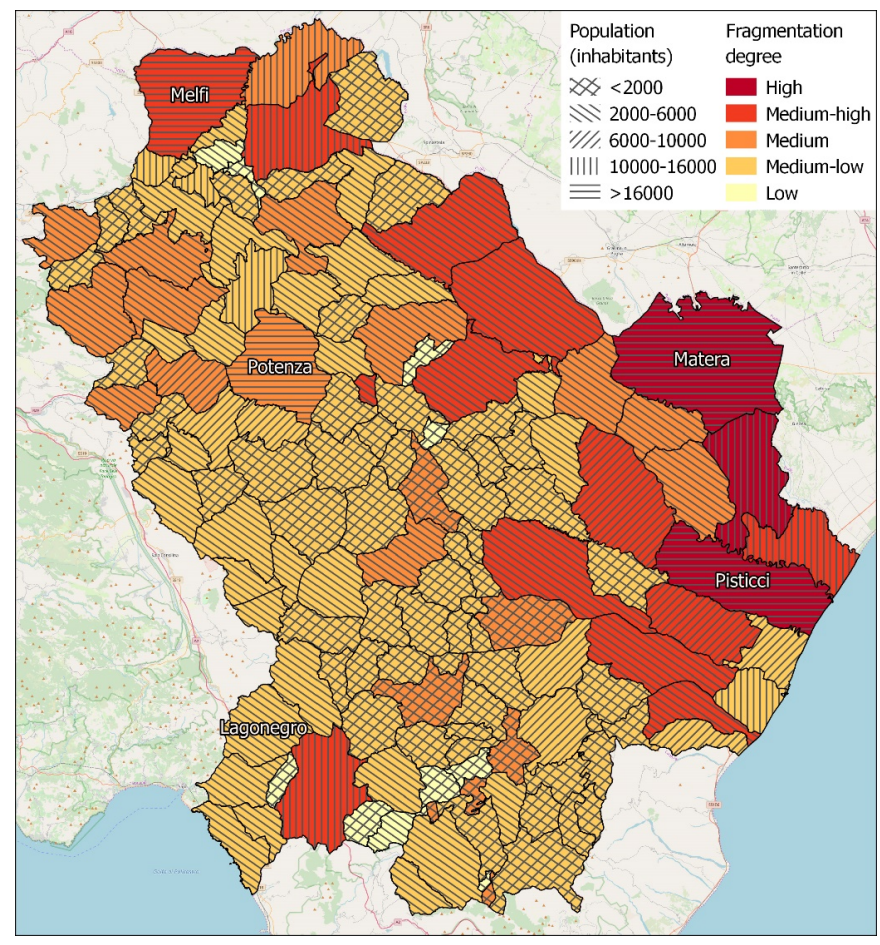

Figure 2. Map of Basilicata region with classification of municipalities for population and the fragmentation degree in the year 2013. Data re-elaborated from the analyses developed in [24]. 
The five municipalities were chosen considering the degree of fragmentation, the resident population, and the morphological characteristics of some territories that have certainly characterized the dynamics of transformation. Potenza, Matera, Melfi, and Pisticci are the first four municipalities in the region per resident population (over 16,000 inhabitants), while Lagonegro is among the municipalities with a population range between 2000 and 6000 inhabitants. For the class of high fragmentation, two municipalities-Matera, the main town of the province, and Pisticci-were chosen. This last municipality is interesting because it is a coastal municipality whose urban transformation is concentrated far from the main center and mainly for tourism purposes. For the medium-high fragmentation class, the municipality of Melfi was chosen, which, with about 17,000 inhabitants, is the third largest municipality in terms of population. The dynamics of transformation have been widely studied in other studies [42]. For the class of average fragmentation, it was decided to analyze the municipality of Potenza, the regional capital and first city by number of inhabitants. The municipality of Lagonegro, which falls in the medium-low fragmentation class, was chosen for its morphological characteristics, its position in the south of the region, and its transformation dynamics that are almost stable over time.

Figure 3 shows the relationship between demographic trends and changes in urbanized areas over twenty years in the municipalities studied and for all the regional territory. Each symbol represents one of the five municipalities analyzed and the regional territory. The symbols in grey represent the variation between 1989 and 1990, while those in red represent the variation between 1990 and 2013.

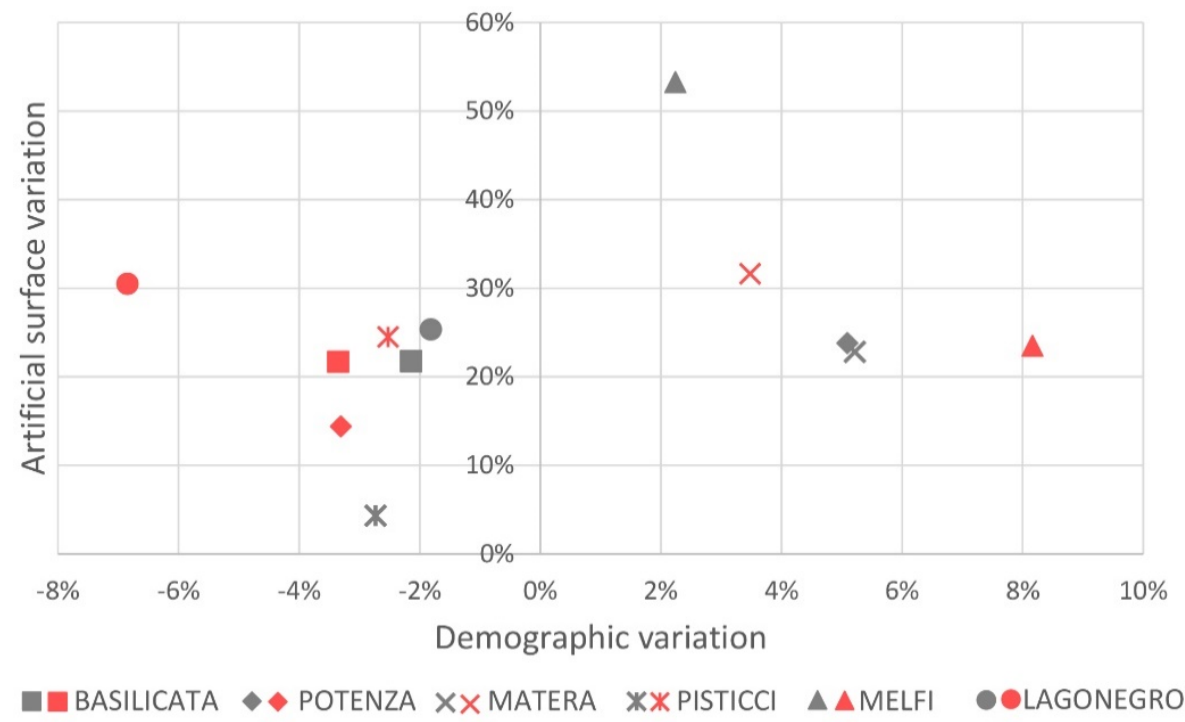

Figure 3. Relation between demographic trends and artificial surface variation over 20 years.

In analyzing the graph, it can be observed that, overall, in the face of a decrease in population, in some cases even substantial, the urbanized area continued to increase. In the case of the municipality of Lagonegro, the one with the smallest population among the municipalities analyzed, in the first decade (1989-1998) a decrease in population of $2 \%$ corresponded to an increase in artificial surface area of $25 \%$, which continued to increase in the second decade with an increase in artificial surface area of $31 \%$ and a further decrease in population of $7 \%$. The same happened for the municipality of Pisticci: a decrease in population corresponded to an increase in artificial surface area. In the municipality of Potenza, in the first decade, a population increase of $5 \%$ corresponded to a $24 \%$ increase in artificial surface area, while in the second decade, a $14 \%$ increase in artificial surface area corresponded to a 3\% decrease in population. For the other two municipalities, Melfi and Matera, a growth of the artificial surface corresponded to a demographic increase. 
As already demonstrated in previous work [24], the increase of artificial surface area in the region in the years considered has increased without a real demand for new residences. Moreover, the increase in artificial surface area was fragmented and affected the phenomenon of sprinkling.

\subsection{Sprinkling Index and Cost Estimation}

The sprinkling index defined by Romano et al. [22] was used in this research to describe the dynamics of territorial transformation. Considering buildings aggregated in complex polygons at a predetermined distance (50 $\mathrm{m}$ according to [24]), and dividing the municipal territory with a grid of 1 square $\mathrm{km}$, the index measures the degree of fragmentation of each analyzed cell. The grid was set casually on the examined territory. The SPX index is a purely geometric measure that found its basis on the Euclidean distance between the different geometries (aggregated buildings) present in the cell and assumes that the most compact and sustainable form of urban growth is that of a circle. The SPX index is expressed by Equation (1):

$$
\mathrm{SPX}=\left\{\sum \sqrt{ }\left[\left(\mathrm{x}_{\mathrm{i}}-\mathrm{x}^{*}\right)^{2}+\left(\mathrm{y}_{\mathrm{i}}-\mathrm{y}^{*}\right)^{2}\right]\right\} / \mathrm{R},
$$

where $x_{i}$ and $y_{i}$ are the coordinates of the centroid of the ith polygon of the urbanized areas that fall in the examined cell, and $x^{*}$ and $y^{*}$ are the coordinates of the centroid of the aggregate larger buildings present in each cell of the grid at the instant considered; $R$ is the radius of the circular area of dimensions like those of the sum of the urbanized areas present in each cell.

The SPX can have a range of values from 0 to $+\infty$ : the higher the index value, the higher the degree of fragmentation of the territory. An SPX equal to zero represents an urban transformation that has occurred in an unfragmented and, therefore, compact way. It expresses the presence in a grid cell of a single aggregate that can occupy the whole cell, with a surface of 1 square $\mathrm{km}$ in this case, or has smaller dimensions.

The SPX index has been calculated for 1950 and 2013 for each cell of the considered municipality, and the gap between them was measured. Figure 4 shows an example of the discretization of the territory of one of the municipalities analyzed and the values of the SPX index relating to each square of the grid.

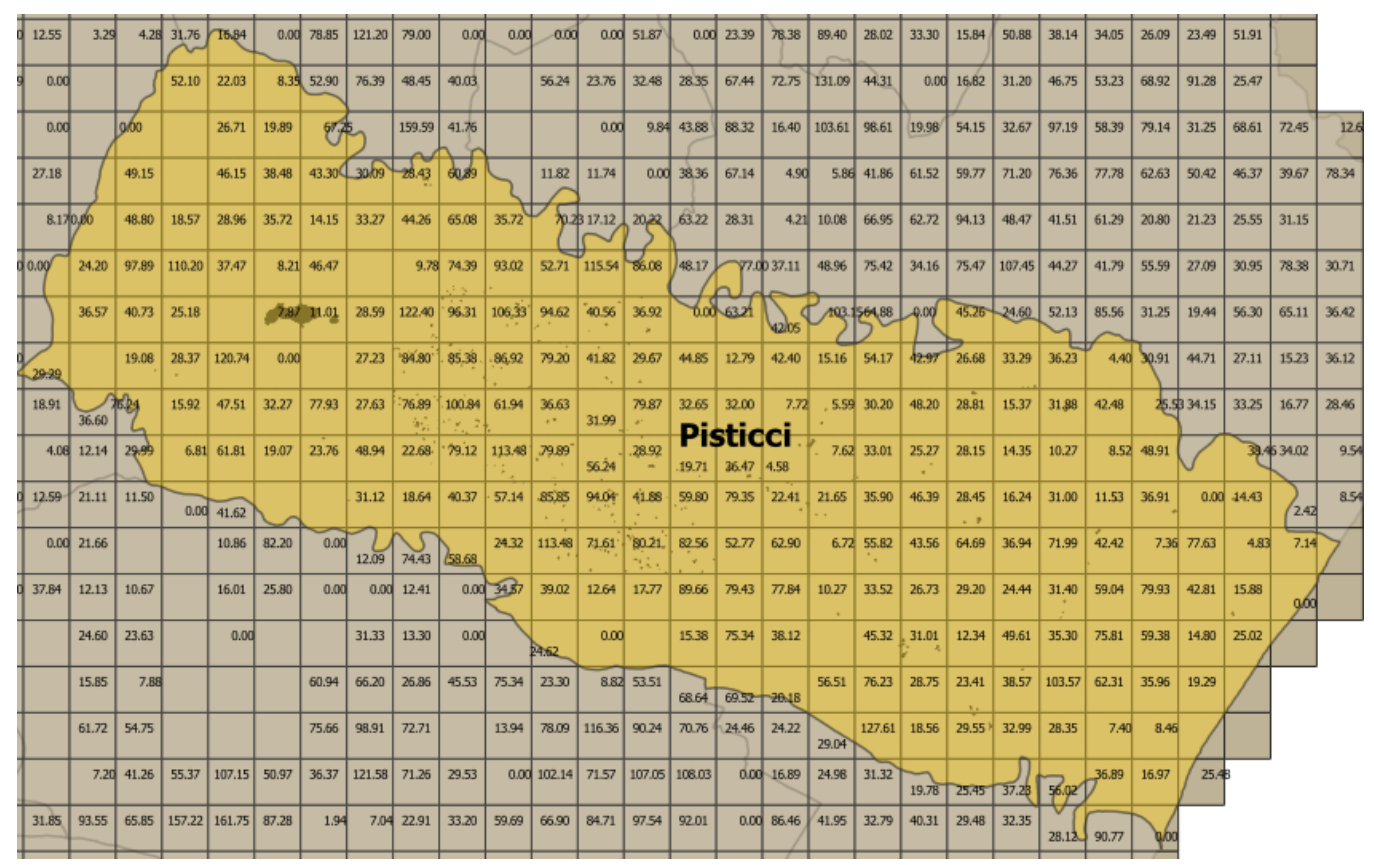

Figure 4. Square mesh grid $(1 \mathrm{~km})$ in the municipality of Pisticci. 
In order to describe the transformation dynamics of the territory, the SPX index was divided into six classes of fragmentation from "not fragmented" to "high fragmentation". The fragmentation classes are shown in Table 1.

Table 1. Fragmentation Degree.

\begin{tabular}{cc}
\hline Fragmentation Degree & SPX $^{\mathbf{1}}$ \\
\hline Not fragmented & $\mathrm{SPX}=0$ \\
Low fragmentation & $0<\mathrm{SPX}<50$ \\
Medium-low fragmentation & $50 \leq \mathrm{SPX}<100$ \\
Medium fragmentation & $100 \leq \mathrm{SPX}<150$ \\
Medium-high fragmentation & $150 \leq \mathrm{SPX}<200$ \\
High fragmentation & $\mathrm{SPX} \geq 200$ \\
\hline${ }^{1}$ All SPX index values were divided by 1000.
\end{tabular}

Comparing the SPX indices measured in 1950 and 2013 made it possible to detect the evolution of the phenomenon within each square of the grid.

Figures 5 and 6 show two examples that highlight the variation of the SPX index over time. The buildings in the two time phases analyzed (1950 and 2013) and the aggregates built around them are represented. Figure 5 shows an example of a decrease in the SPX due to the increase in the size of the main aggregate present in 1950 following the construction of new buildings close to the existing ones. We define this urban transformation dynamic as compaction dynamics. Figure 6 shows the opposite situation, which is an increase in the SPX index. In the cell from 1950 to 2013, the size of the existing aggregates increased, but new buildings were also built far away from them. This transformation dynamic is exactly that of sprinkling.

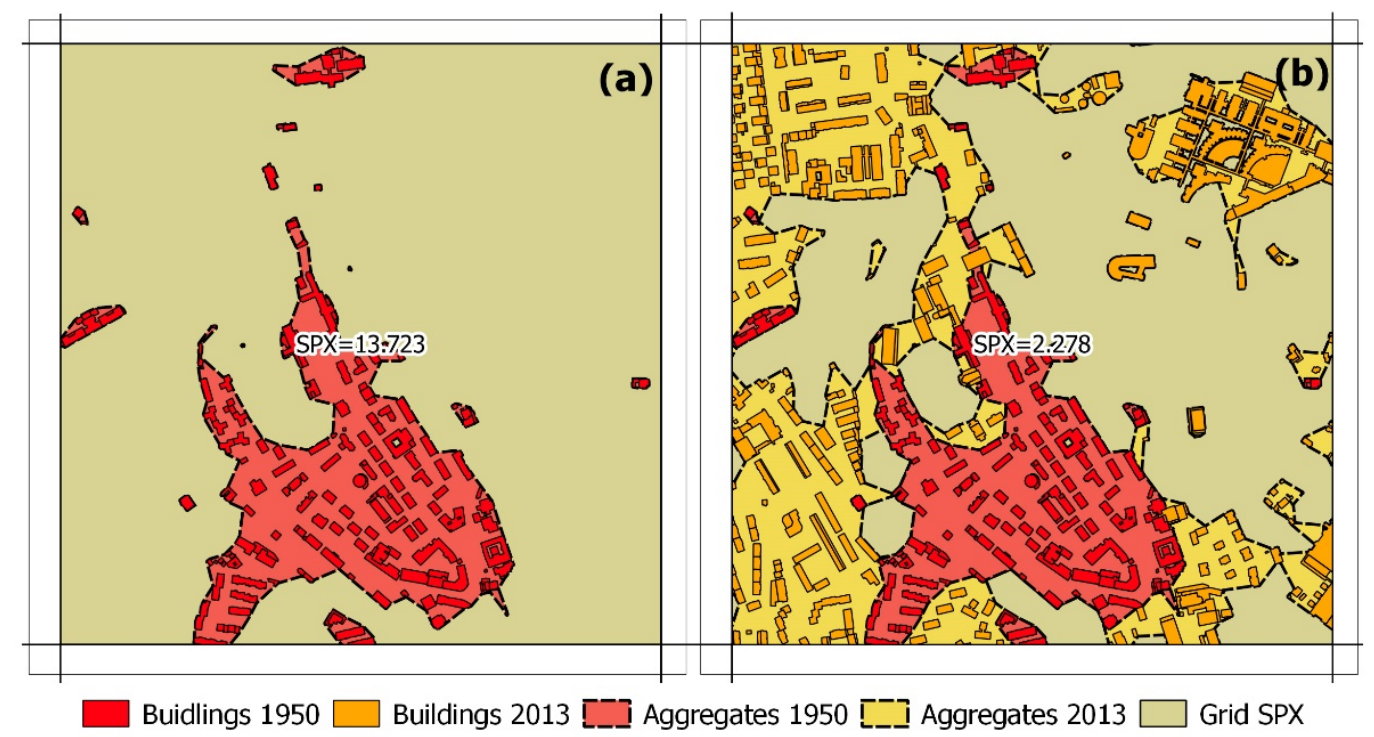

Figure 5. Example of reduction of the SPX index: (a) 1950; (b) 2013.

A sample of 57 cells belonging to the five municipalities was selected. These had undergone the greatest territorial transformations, i.e., the SPX index changed from 1950 to 2013. Of these cells, only those in which the SPX index increased were analyzed. An increase in the index corresponds, in fact, to an increase in fragmentation. The index increased for 15 cells, and the analyses carried out on these cells are illustrated below. To better clarify the choice, the regression analysis was also carried out on the meshes with negative $\triangle \mathrm{SPX}$ (42) demonstrating in this case, as expected, that there is no statistically significant relationship between the variables taken into consideration. 


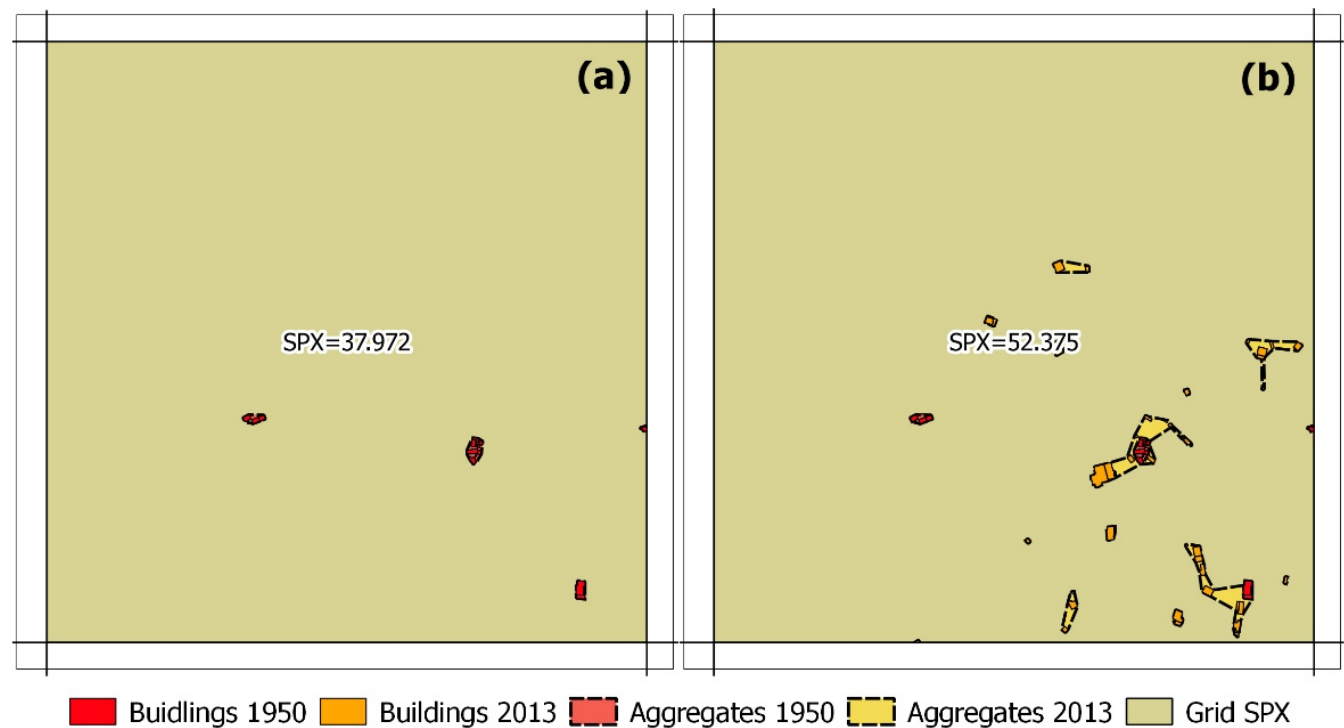

Figure 6. Example of an increase in the SPX index: (a) 1950; (b) 2013.

In the regression model, the cost of linear infrastructures (roads, underground services, public lighting, etc.) per unit volume of building (cubic meters) was taken as a dependent variable, while the following were considered as independent predictors or variables:

- the variation in sprinkling, defined by the difference,

$$
\Delta_{\mathrm{SPX}, \mathrm{I}}=\mathrm{SPX}_{\mathrm{i}(2013)}-\mathrm{SPX}_{\mathrm{i}(1950)}
$$

- the mean square deviation, $S$, of the elevation values $(X)$ measured every 5 square meters within the reference mesh,

$$
S_{i}=\sqrt{\frac{\sum_{i=1}^{n}\left(X_{i}-\bar{X}\right)^{2}}{n-1}}
$$

Index $\mathrm{S}$ is representative of the orographic complexity of the mesh. Meshes with strong variations in altitude have higher values of this parameter compared to almost flat meshes.

The idea behind the choice of this second predictive variable is that the orographic conformation of the single mesh affects the cost of infrastructure. A geomorphological conformation with greater elevation differences entails a certainly more complex road network layout, which obviously is reflected in the costs of this infrastructure.

To estimate the construction costs of the road infrastructure, all road sections within each mesh were identified, and for each of them, the type was identified and the length defined.

The length of each road section was determined approximately by placing it equal to its semiperimeter. Given the lack of information relating to the year of construction of the roads, by a comparison between the map of the residential buildings surveyed in 1950 and 2013 and a subsequent overlap with the road cartography, it was assumed that urban and local roads outside the inhabited centers (in 1950), different from those which were the main routes, had been built precisely in this interval to allow accessibility to the new construction. It was also hypothesized that any roads dating back to the year 1950 or earlier, serving buildings outside the existing urban perimeters, were mostly configured as sheep tracks made of clay. Therefore, although already existing, they have been considered in calculating the new infrastructures generated by sprinkling. As mentioned, extra-urban roads (main and secondary) and highways were excluded from the calculation.

For the definitions of the physical and geometric characteristics of the road superstructures of each type, the indications provided by the Road Paving Catalog drawn up by the CNR (National 
Research Center) were used. This catalog assigns the thicknesses to the different layers of the pavement according to the number of passages of commercial vehicles, the climatic conditions, and the type of substrate (which expresses their bearing capacity). Finally, quantities were determined to define the construction costs of the road sections, which defined the costs per linear meter for the different categories of roads (as described by the Highway Code), based on the items reported in the price list of the Basilicata region.

To estimate the average costs of water and sewage networks and public lighting systems, price lists known in the literature were used that define a detailed reference of parametric prices for various urbanization works.

Subsequently, the volumes of residential buildings built after 1950 were measured, calculating the product of the height per building area. Finally, the cost of urbanization was weighed on the volumes present in each mesh of the grid, and the costs per unit of volume were estimated.

\section{Results}

In Table 2 are the data used for the analyses.

Table 2. Input Data.

\begin{tabular}{cccc}
\hline \multirow{2}{*}{ Town } & Response & \multicolumn{2}{c}{ Predictors } \\
\cline { 2 - 4 } & Cost $\left(\boldsymbol{\epsilon} / \mathbf{m}^{\mathbf{3}}\right)$ & $\Delta \mathbf{S P X}$ & $\mathbf{S}$ \\
\hline \multirow{2}{*}{ Potenza } & 32.196 & 14.573 & 47.68 \\
\cline { 2 - 4 } & 44.907 & 45.795 & 27.49 \\
\hline \multirow{2}{*}{ Lagonegro } & 44.163 & 14.403 & 37.165 \\
\cline { 2 - 4 } & 60.807 & 27.085 & 81.987 \\
\cline { 2 - 4 } Matera & 26.754 & 5548 & 68.53 \\
\cline { 2 - 4 } & 10.851 & 3055 & 7917 \\
\hline \multirow{2}{*}{ Melfi } & 110.563 & 101.17 & 855 \\
\cline { 2 - 4 } & 31.865 & 20.161 & 4.46 \\
\hline \multirow{2}{*}{ Pisticci } & 35.918 & 65.991 & 21.789 \\
\cline { 2 - 4 } & 17.642 & 4023 & 52.988 \\
\cline { 2 - 4 } & 32.608 & 20.177 & 24.51 \\
\hline & 23.771 & 7177 & 4935 \\
\hline & 31.779 & 11.77 & 8242 \\
\hline & 9821 & 4817 & 17.932 \\
\hline & 32.786 & 39.344 & 29.444 \\
\hline
\end{tabular}

Simple linear regression was primarily developed by assuming the SPX index as the only explanatory variable. Table 3, Figures 7 and 8 describe the results. They show a good fit of the model with R2 of 0.69 . Considering the layout of the observed points, that some of them had a measure of the variation of the SPX index very close to zero, and that if $\triangle \mathrm{SPX}=0$ the variation of the cost must also be zero, the power regression was also processed (Figure 9). In this case, R2 increased to 0.71 (Table 4). In the last two data processing analyses, multiple linear regression was developed by assuming as predictors both the variation of the SPX index and the orographic complexity index (S) with and without the constant. In the regression with the constant, the R2 increased to 0.73 , but the indicators of statistical significance of the predictors discarded both the constant and S (Table 5 and Figure 10). In the regression without the constant, the model showed a better fit to the observed data $(\mathrm{R} 2=0.91)$, and for both explanatory variables, the null hypothesis was rejected (Table 6 and Figure 11). 
Table 3. Simple Linear Regression Statistics.

\begin{tabular}{|c|c|c|c|c|c|c|c|}
\hline \multicolumn{2}{|c|}{$\mathrm{R}$} & 0.8301 & \multicolumn{2}{|c|}{ R-squared } & 0.68906 & Adjusted R-squared & 0.66515 \\
\hline \multicolumn{2}{|c|}{ MSE } & 198.02889 & \multicolumn{2}{|c|}{ S } & 14.07227 & MAPE & 33.34135 \\
\hline \multicolumn{2}{|c|}{ Durbin-Watson (DW) } & 1.65484 & \multicolumn{2}{|c|}{ Log likelihood } & -59.87392 & & \\
\hline \multicolumn{2}{|c|}{ Akaike inf. criterion (AIC) } & 8.24986 & \multicolumn{2}{|c|}{ AICc } & 8.27037 & & \\
\hline \multicolumn{2}{|c|}{ Schwarz criterion (BIC) } & 8.34426 & \multicolumn{2}{|c|}{ Hannan-Quinn criterion (HQC) } & 8.24885 & & \\
\hline \multicolumn{2}{|c|}{ PRESS } & 5298.72 & \multicolumn{2}{|c|}{ PRESS RMSE } & 18.79489 & Adjusted R-squared & 0.36001 \\
\hline & Coefficients & Std Err & $\mathrm{LCL}^{1}$ & $\mathrm{UCL}^{1}$ & t Stat & Value $\mathrm{p}$ & H0 (5\%) \\
\hline Constant & 17.58168 & 5.05288 & 6.66559 & 28.49776 & 3.47953 & 0.00407 & rejected \\
\hline$\triangle \mathrm{SPX}$ & 0.73413 & 0.13677 & 0.43864 & 1.02961 & 5.36742 & 0.00013 & rejected \\
\hline
\end{tabular}

${ }^{1}$ LCL-Lower limit 95\% confidence interval. UCL-Upper limit 95\% confidence interval.

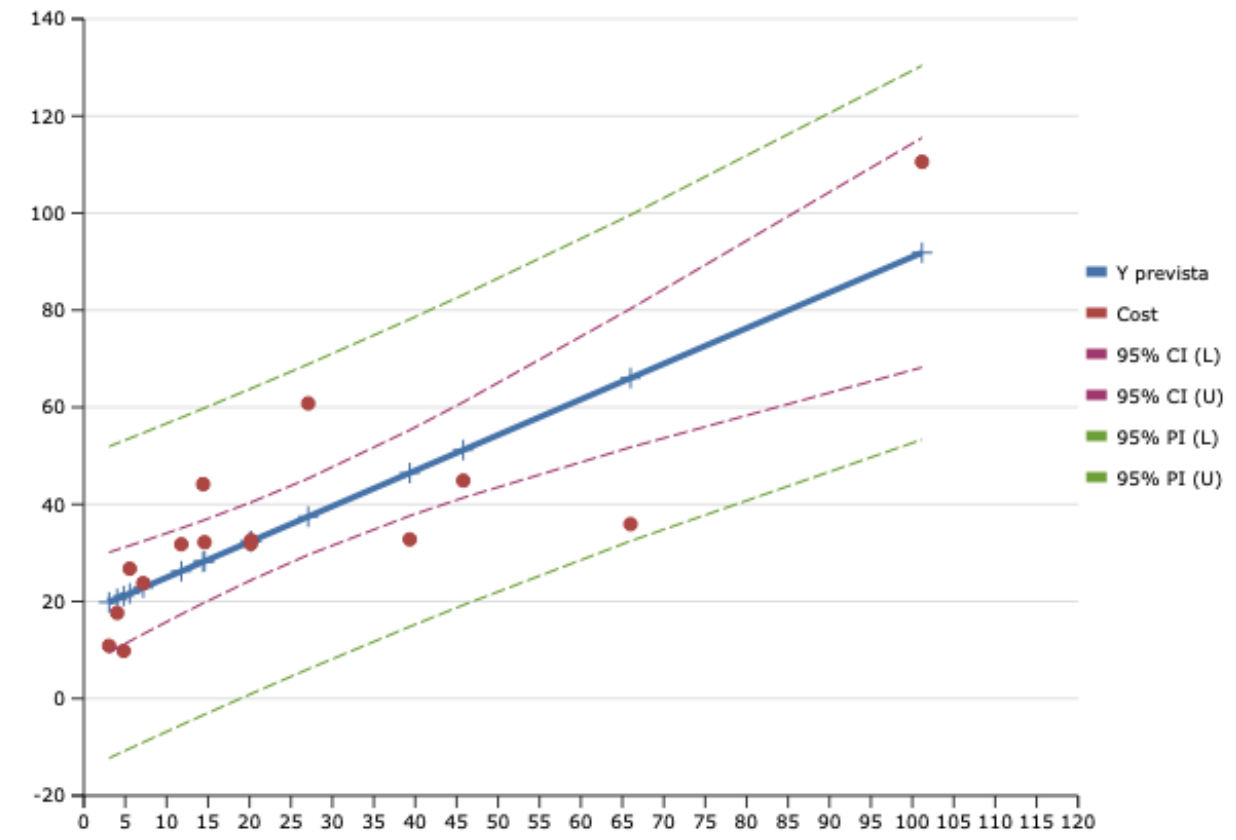

Figure 7. Simple Linear Regression.

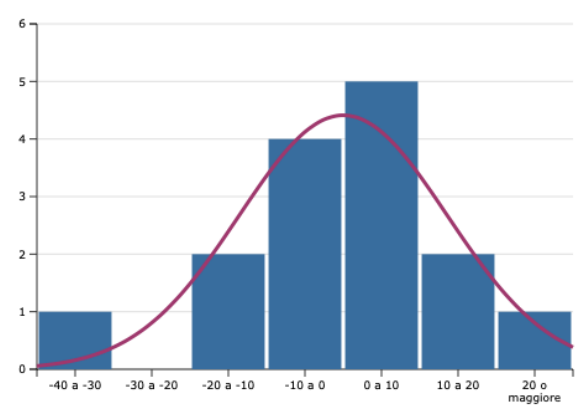

(a)

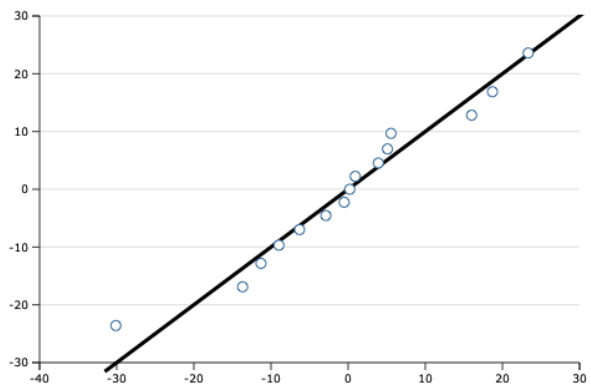

(b)

Figure 8. Histogram (a) and Normal QQ-plot (b) for residuals in simple linear regression. 


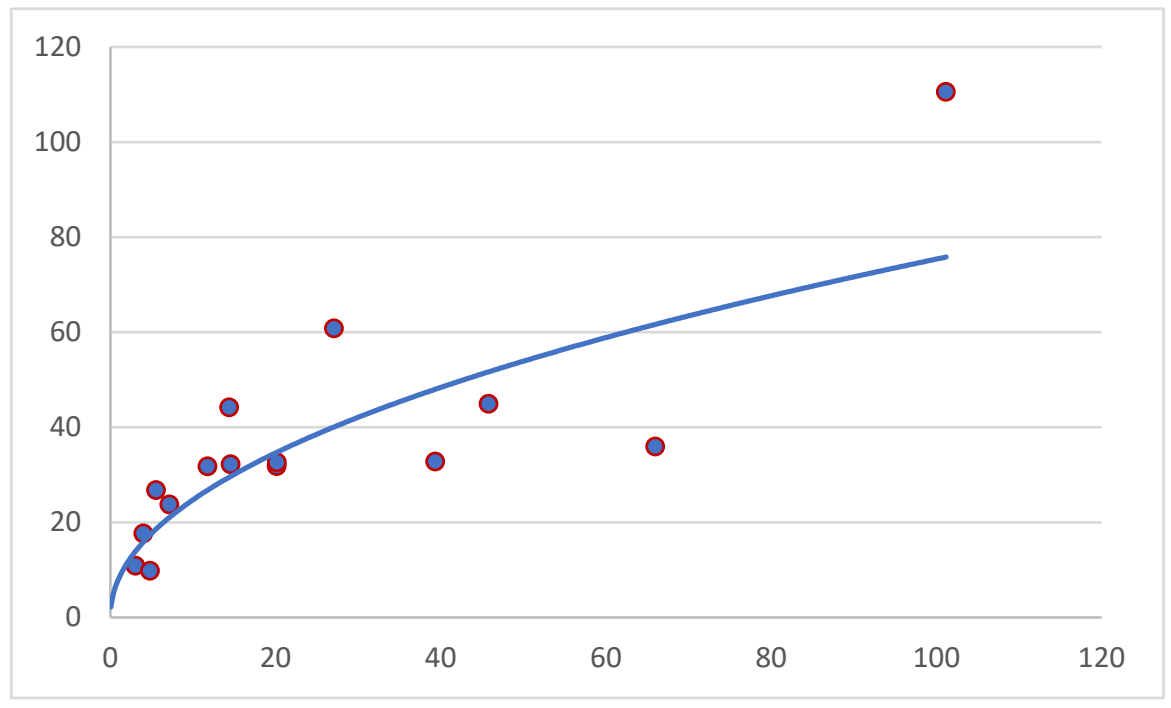

Figure 9. Power regression.

Table 4. Power Regression Statistics.

\begin{tabular}{cccccc}
\hline $\mathbf{R}$ & R-squared & \multicolumn{2}{c}{ Adjusted R-squared } & \multicolumn{2}{c}{ Standard Error of the Estimate } \\
\hline 0.840 & 0.706 & \multicolumn{2}{c}{0.683} & \multicolumn{2}{c}{0.343} \\
\hline & Coefficients & Std Err & Std Coefficients & T Stat & Value $\mathrm{p}$ \\
\hline $\ln (\Delta \mathrm{SPX})$ & 0.484 & 0.087 & 0.840 & 5.585 & 0.000 \\
\hline Constant & 8.123 & 2.062 & & 3.940 & 0.002 \\
\hline
\end{tabular}

Table 5. Multiple Linear Regression Statistics with the Constant.

\begin{tabular}{|c|c|c|c|c|c|c|c|}
\hline \multicolumn{2}{|c|}{$\mathrm{R}$} & 0.85385 & \multicolumn{2}{|c|}{ R-Squared } & 0.72906 & Adjusted R-Squared & 0.6839 \\
\hline \multicolumn{2}{|c|}{ MSE } & 186.9357 & \multicolumn{2}{|c|}{$S$} & 13.67244 & MAPE & 30.73977 \\
\hline \multicolumn{2}{|c|}{ Durbin-Watson (DW) } & 1.68796 & \multicolumn{2}{|c|}{ Log likelihood } & -58.84124 & & \\
\hline \multicolumn{2}{|c|}{ Akaike inf. criterion (AIC) } & 8.2455 & \multicolumn{2}{|c|}{ AICc } & 8.31216 & & \\
\hline \multicolumn{2}{|c|}{ Schwarz criterion (BIC) } & 8.38711 & \multicolumn{2}{|c|}{ Hannan-Quinn criterion (HQC) } & 8.24399 & & \\
\hline \multicolumn{2}{|c|}{ PRESS } & 5738.40 & \multicolumn{2}{|c|}{ PRESS RMSE } & 19.55914 & Adjusted R-squared & 0.30691 \\
\hline & Coefficients & Std Err & LCL & UCL & $\mathrm{t}$ Stat & Value $\mathrm{p}$ & H0 (5\%) \\
\hline Constant & 10.55533 & 7.20909 & -5.15192 & 26.26258 & 1.46417 & 0.16885 & accepted \\
\hline$\triangle \mathrm{SPX}$ & 0.76928 & 0.13549 & 0.47408 & 1.06448 & 5.67785 & 0.0001 & rejected \\
\hline S & 0.20707 & 0.15558 & -0.13191 & 0.54604 & 1.33096 & 0.20794 & accepted \\
\hline
\end{tabular}

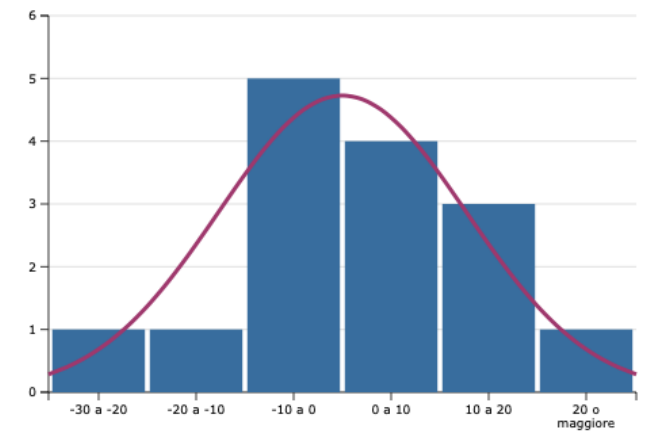

(a)

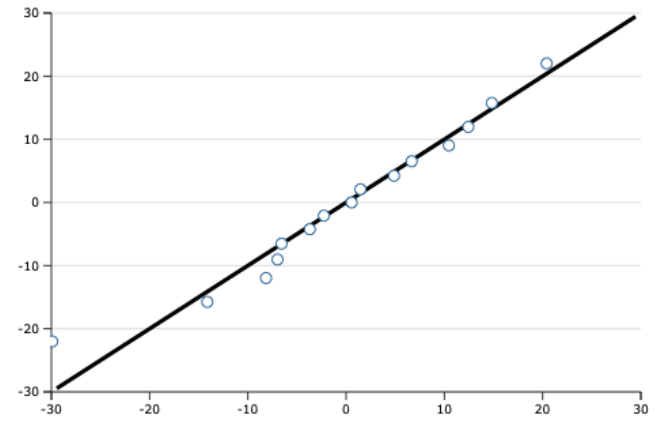

(b)

Figure 10. Histogram (a) and Normal QQ-plot (b) for residuals in multiple linear regression with the constant. 
Table 6. Multiple Linear Regression Statistics without the Constant.

\begin{tabular}{|c|c|c|c|c|c|c|c|}
\hline \multicolumn{2}{|c|}{$\mathrm{R}$} & 0.95194 & \multicolumn{2}{|c|}{ R-Squared } & 0.90619 & Adjusted R-Squared & 0.89898 \\
\hline \multicolumn{2}{|c|}{ MSE } & 203.38309 & \multicolumn{2}{|c|}{ S } & 14.26124 & MAPE & 32.93767 \\
\hline \multicolumn{2}{|c|}{ Durbin-Watson (DW) } & 1.64565 & \multicolumn{2}{|c|}{ Log likelihood } & -60.07401 & & \\
\hline \multicolumn{2}{|c|}{ Akaike inf. criterion (AIC) } & 8.27653 & \multicolumn{2}{|c|}{ AICc } & 8.33807 & & \\
\hline \multicolumn{2}{|c|}{ Schwarz criterion (BIC) } & 8.37094 & \multicolumn{2}{|c|}{ Hannan-Quinn criterion (HQC) } & 8.27553 & & \\
\hline \multicolumn{2}{|c|}{ PRESS } & 4918.98 & \multicolumn{2}{|c|}{ PRESS RMSE } & 18.1089 & Adjusted R-squared & 0.82548 \\
\hline & Coefficients & Std Err & LCL & $\mathrm{UCL}$ & t Stat & Value $\mathrm{p}$ & H0 (5\%) \\
\hline Constant & 0 & & & & & & \\
\hline$\triangle \mathrm{SPX}$ & 0.88968 & 0.11232 & 0.64703 & 1.13233 & 7.92095 & $2.49 \mathrm{E}-06$ & rejected \\
\hline$S$ & 0.37388 & 0.11051 & 0.13514 & 0.61261 & 3.38322 & 0.0049 & rejected \\
\hline
\end{tabular}

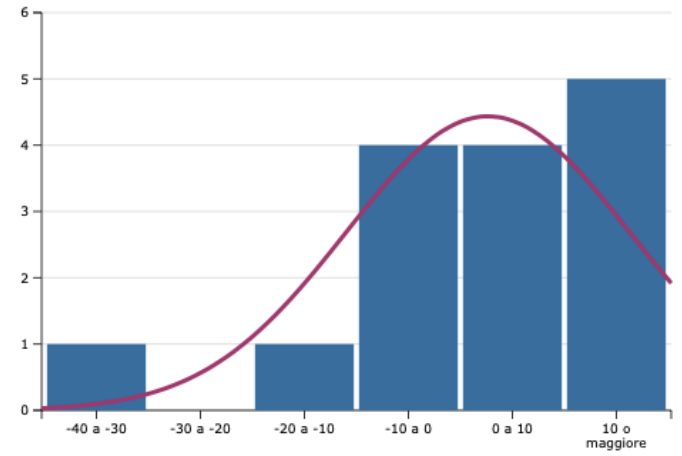

(a)

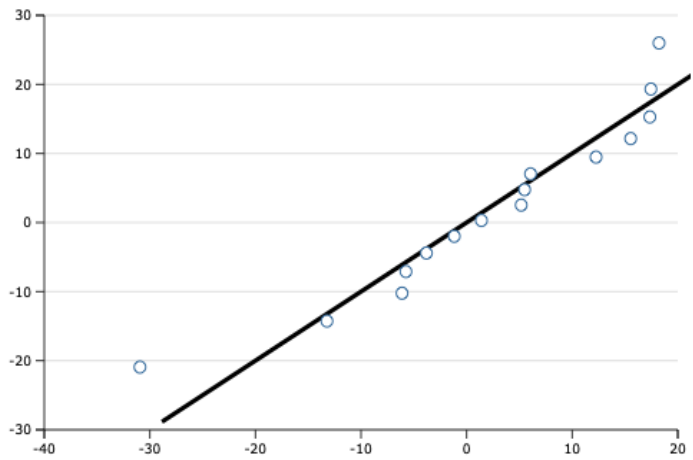

(b)

Figure 11. Histogram (a) and Normal QQ-plot (b) for residuals in multiple linear regression without the constant.

\section{Discussion}

Analysis of the models showed that a unit increase in the SPX index produced an additional cost that weighed on the population due to the greater linear infrastructures serving widespread and fragmented urbanization, which varied in the range between $€ 0.73$ and $€ 0.89$ per cubic meter of total built volume (new and existing). This means that in the passage from one degree of urban fragmentation (SPX) to the next (see Table 4), the cost increase is estimated in the range $€ 36.50-44.50 / \mathrm{m}^{3}$. If it is assumed that each inhabitant occupies about 100-120 cubic meters, the per capita cost, resulting from the increase in a degree of urban fragmentation, is approximately $€ 4000.00$.

The cost of sprinkling calculated in this way certainly has a social character, and it falls directly on the entire population. A new residential complex far from the main urban center needs new services that, in turn, require new road infrastructure and additional costs for the population. What drives users to build new houses in the rural landscape, isolated from existing residential complexes? Surely, a triggering factor lies in the tax benefits related to infrastructure for new homeowners, the lower costs of agricultural land, and the need for a new residence (sometimes a second residence) away from the chaos of the city.

If we transfer the cost calculated per capita on the cells of 1 square $\mathrm{km}$ analyzed in the following research, we obtain the cost of sprinkling per square $\mathrm{km}$. For example, for the municipality of Matera, in one of the cells analyzed, we obtained $\Delta \mathrm{SPX}=101.17$ (see Table 2), which means a passage of two classes of fragmentation. Considering that the population density of the municipality of Matera is 57 inhabitants per square $\mathrm{km}$, we could say (intensifying the result) that the new transformations occurred in the above cell between 1950 and 2013, and that the following the dynamics of urban sprinkling generated a cost of $€ 228,000$ per square $\mathrm{km}$ and per transition of fragmentation class.

In addition, other considerations come from analyzing each municipality's cell with the highest SPX variation. For each municipality, the hypothetical resident (or inhabitable) population per cell was 
calculated by dividing the existing volume by $120 \mathrm{~m}^{3}$ per inhabitant. It follows, obviously, that the municipalities classified with a high degree of fragmentation (Matera and Pisticci municipalities) have a high cost. In a specific case, the cost of sprinkling in a single cell in Pisticci is $€ 1,060,000.00$, while in Matera it is $€ 736,000.00$. In the municipality of Matera, the difference in the SPX index is equal to the passage of two classes of fragmentation, and for this reason, the cost has been doubled. Figure 12 shows the cost and the SPX index difference for each cell analyzed in the five municipalities.

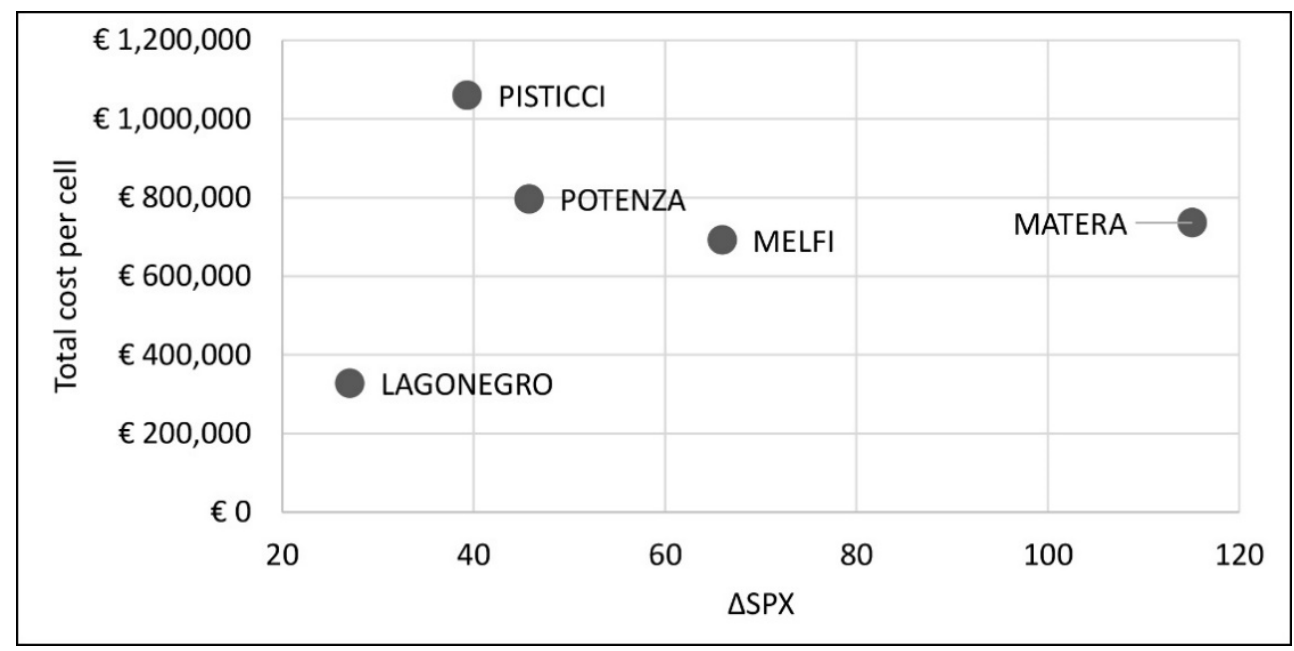

Figure 12. Total cost per cell analyzed for each municipality.

The municipalities of Potenza and Melfi have costs that are around $€ 700,000$. For the municipality of Lagonegro, which is classified with a medium-low fragmentation degree, the cost is much lower: $€ 328,000$. This shows that low levels of fragmentation have much lower costs than higher levels of fragmentation.

\section{Conclusions}

Starting from a previous study conducted at the University of Basilicata [24] aimed at measuring widespread urbanization and sprinkling and reconstructing its dynamics in the municipalities of the Basilicata region, this research examined the phenomenon from an economic point of view. It focused on the most evident social costs that are consequent to the greater linear infrastructure deriving from urban fragmentation.

The idea behind the research was to analyze a primary relationship between the costs of urbanization and the quantitative measure of sprinkling already defined in the mentioned work. The results of the analyses demonstrated the goodness-of-fit of the model and the significance of the explanatory variables selected.

Further research developments involve experimentation and verification of the model by applying it to a sample of more numerous data both on the regional scale of Basilicata and in other regional areas.

Dissemination of the results of this experimentation will serve to gain further awareness of the serious negative impacts of uncontrolled urbanization. While on the one hand, the literature has already widely highlighted the indirect consequences, the direct consequences in terms of higher expenses that administrations incur are seldom investigated. Even limiting the analysis of costs to major linear infrastructure, as this research has done, the significant per capita impact of these costs translates into fewer and worse services that the local administration can guarantee its citizens. Awareness of the burdens that weigh directly on citizens constitutes a warning for those who govern the territory. This evidence could direct administrations towards adequate planning aimed at curbing widespread urbanization by imposing limitations on further taking land, favoring the maintenance of soil permeability and the protection of residual open space. 
Interventions can support these activities to improve the quality of life in urban areas, to consolidate them and the infrastructures that serve them, to efficiently manage public housing assets, to cooperate with municipalities in planning new developments, and to encourage reuse through taxation of the disused real estate assets.

Author Contributions: Conceptualization and investigation: B.M. (Benedetto Manganelli); methodology, data curation, visualization, writing-review and editing: B.M. (Benedetto Manganelli), B.M. (Beniamino Murgante), L.S. All authors have read and agreed to the published version of the manuscript.

Funding: This research received no external funding.

Conflicts of Interest: The authors declare no conflict of interest.

\section{References}

1. Burchell, R.W.; Downs, A.; McCann, B.; Mukherji, S. Sprawl Costs: Economic Impacts of Unchecked Development; Island Press: Washington, DC, USA, 2005; 197p.

2. Bruegmann, R. Sprazwl: A Compact History, 1st ed.; University of Chicago Press: Chicago, IL, USA, 2005.

3. Tu, J.; Xia, Z.G.; Clarke, K.C.; Frei, A. Impact of urban sprawl on water quality in eastern Massachusetts, USA. Environ. Manag. 2007, 40, 183-200. [CrossRef]

4. Borrego, C.; Martins, H.; Tchepel, O.; Salmim, L.; Monteiro, A.; Miranda, A.I. How urban structure can affect city sustainability from an air quality perspective. Environ. Model. \& Softw. 2006, 21, 461-467.

5. Bhatta, B. Analysis of Urban Growth and Sprawl from Remote Sensing Data; Springer: Berlin/Heidelberg, Germany, 2010; pp. 17-36.

6. Stone, B. Urban sprawl and air quality in large US cities. J. Environ. Manag. 2008, 86, 688-698. [CrossRef] [PubMed]

7. Wilson, B.; Chakraborty, A. The environmental impacts of sprawl: Emergent themes from the past decade of planning research. Sustainability 2013, 5, 3302-3327. [CrossRef]

8. Ewing, R.H. Characteristics, causes, and effects of sprawl: A literature review. In Urban Ecology; Marzluff, J., Shulenberger, E., Endlicher, W., Alberti, M., Bradley, G., Ryan, C., ZumBrunnen, C., Simon, U., Eds.; Springer: New York, NY, USA, 2008; pp. 519-535.

9. Travisi, C.M.; Camagni, R.; Nijkamp, P. Impacts of urban sprawl and commuting: A modelling study for Italy. J. Transp. Geogr. 2010, 18, 382-392. [CrossRef]

10. Johnson, M.P. Environmental impacts of urban sprawl: A survey of the literature and proposed research agenda. Environ. Plan. A 2001, 33, 717-735. [CrossRef]

11. Gonzalez, G.A. Urban sprawl, global warming and the limits of ecological modernization. Environ. Politics 2005, 14, 344-362. [CrossRef]

12. Camagni, R.; Cristina, M.G.; Rigamonti, P. Urban mobility and urban form: The social and environmental costs of different patterns of urban expansion. Ecol. Econ. 2002, 40, 199-216. [CrossRef]

13. Newman, P.W.G.; Kenworthy, J.R.; Vintila, P. Can we overcome automobile dependence? Physical planning in an age of urban cynicism. Cities 1995, 12, 53-65. [CrossRef]

14. Cervero, R. Jobs-Housing balance revisited: Trends and impacts in the San Francisco Bay Area. J. Am. Plan. Assoc. 1996, 62, 492-511. [CrossRef]

15. Power, A. Social exclusion and urban sprawl: Is the rescue of cities possible? Reg. Stud. 2001, 35, 731-742. [CrossRef]

16. Le Goix, R. Gated communities: Sprawl and social segregation in Southern California. Hous. Stud. 2005, 20, 323-343. [CrossRef]

17. Brueckner, J.K. Urban Sprawl: Diagnosis and Remedies. Int. Reg. Sci. Rev. 2000, 23, 160-171. [CrossRef]

18. Litynski, P.; Holuj, A. Urban Sprawl Costs: The Valuation of Households' Losses in Poland. J. Settl. Spat. Plan. 2017, 8, 11-35. [CrossRef]

19. Ladd, H.F. Population Growth, Density and the Costs of Providing Public Services. Urban Stud. 1992, 29, 273-295. [CrossRef]

20. Carruthers, J.I.; Ulfarsson, G.F. Urban sprawl and the cost of public services. Environ. Plan. B Plan. Des. 2003, 30, 503-522. [CrossRef] 
21. Hortas-Rico, M.; Sole'-Olle', A. Does urban sprawl increase the costs of providing local public services? Evidence from Spanish municipalities. Urban Stud. 2010, 47, 1513-1540. [CrossRef]

22. Romano, B.; Zullo, F.; Fiorini, L.; Ciabò, S.; Marucci, A. Sprinkling: An Approach to Describe Urbanization Dynamics in Italy. Sustainability 2017, 9, 97. [CrossRef]

23. Saganeiti, L.; Pilogallo, A.; Scorza, F.; Mussuto, G.; Murgante, B. Spatial indicators to evaluate urban fragmentation in Basilicata region. In International Conference on Computational Science and Its Applications; Springer: Cham, Switzerland, 2018; Volume 10964, ISBN 9783319951737.

24. Saganeiti, L.; Favale, A.; Pilogallo, A.; Scorza, F.; Murgante, B. Assessing Urban Fragmentation at Regional Scale using Sprinkling Indexes. Sustainability 2018, 10, 3274. [CrossRef]

25. Nechyba, T.J.; Walsh, R.P. Urban sprawl. J. Econ. Perspect. 2004, 18, 177-200. [CrossRef]

26. Jaeger, J.A.G.; Bertiller, R.; Schwick, C.; Kienast, F. Suitability criteria for measures of urban sprawl. Ecol. Indic. 2010, 10, 397-406. [CrossRef]

27. Kew, B.; Lee, B.D. Measuring sprawl across the urban rural continuum using an amalgamated sprawl index. Sustainability 2013, 5, 1806-1828. [CrossRef]

28. Galster, G.; Hanson, R.; Ratcliffe, M.R.; Wolman, H.; Coleman, S.; Freihage, J. Wrestling sprawl to the ground: Defining and measuring an elusive concept. Hous. Policy Debate 2001, 12, 681-717. [CrossRef]

29. Brueckner, J.K. Urban Sprawl: Lessons from Urban Economics. Brook.-Whart. Pap. Urban Aff. 2001, 2001, 65-97. [CrossRef]

30. Urban Sprawl | Definition of Urban Sprawl at Dictionary.com. Available online: https://www.merriamwebster.com/dictionary/urbansprawl (accessed on 14 December 2019).

31. Romano, B.; Zullo, F.; Ciabò, S.; Fiorini, L.; Marucci, A. Geografie e modelli di 50 anni di consumo di suolo in Italia. Sci. E Ric. 2015, 5, 17-28.

32. Xu, G.; Dong, T.; Cobbinah, P.B.; Jiao, L.; Sumari, N.S.; Chai, B.; Liu, Y. Urban expansion and form changes across African cities with a global outlook: Spatiotemporal analysis of urban land densities. J. Clean. Prod. 2019, 224, 802-810. [CrossRef]

33. Urbieta, P.; Fernandez, E.; Ramos, L.; Méndez Martínez, G.; Bento, R. A land-cover based urban dispersion indicator suitable for highly dispersed, discontinuously artificialized territories: The case of continental Portugal. Land Use Policy 2019, 85, 92-103. [CrossRef]

34. Saganeiti, L.; Pilogallo, A.; Faruolo, G.; Scorza, F.; Murgante, B. Territorial Fragmentation and Renewable Energy Source Plants: Which Relationship? Sustainability 2020, 12, 1828. [CrossRef]

35. Sudhira, H.S.; Ramachandra, T.V.; Jagadish, K.S. Urban sprawl: Metrics, dynamics and modelling using GIS. Int. J. Appl. Earth Obs. Geoinf. 2004, 5, 29-39. [CrossRef]

36. Malpezzi, S.; Guo, W.K. Measuring Sprawl: Alternative Measures of Urban Form in U.S. Metropolitan Areas; The Center for Urban Land Economics Research; University of Wisconsin: Madison, WI, USA, 2001.

37. Bhatta, B.; Saraswati, S.; Bandyopadhyay, D. Urban sprawl measurement from remote sensing data. Appl. Geogr. 2010, 30, 731-740. [CrossRef]

38. Hasse, J. A geospatial approach to measuring new development tracts for characteristics of sprawl. Landsc. J. 2004, 23, 52-67. [CrossRef]

39. Hennig, E.I.; Schwick, C.; Soukup, T.; Orlitová, E.; Kienast, F.; Jaeger, J.A.G. Multi-scale analysis of urban sprawl in Europe: Towards a European de-sprawling strategy. Land Use Policy 2015, 49, 483-498. [CrossRef]

40. Torrens, P.M. A toolkit for measuring sprawl. Appl. Spat. Anal. 2008, 1, 5-36. [CrossRef]

41. Istat.it. Available online: https://www.istat.it/ (accessed on 5 April 2018).

42. Scorza, F.; Pilogallo, A.; Saganeiti, L.; Murgante, B.; Pontrandolfi, P. Comparing the territorial performances of Renewable Energy Sources' plants with an integrated Ecosystem Services loss assessment: A case study from the Basilicata region (Italy). Sustain. Cities Soc. 2020, 56, 102082. [CrossRef]

(C) 2020 by the authors. Licensee MDPI, Basel, Switzerland. This article is an open access article distributed under the terms and conditions of the Creative Commons Attribution (CC BY) license (http://creativecommons.org/licenses/by/4.0/). 